\title{
TEN YEARS OF ACTH THERAPY
}

BY

\author{
H. F. WEST*
}

Sheffield

We began to give corticotrophin to patients suffering from rheumatoid arthritis (R.A.) and ankylosing spondylitis (A.S.) in 1951. Since November, 1952, the amount of adrenal stimulation given to each patient has been kept under review by repeated urinary assays for 17-ketogenic steroids (17-KGS: Norymberski, Stubbs, and West, 1953), or for total 17-hydroxy-corticosteroids $(17(\mathrm{OH}) \mathrm{CS}$ : Appleby, Gibson, Norymberski, and Stubbs, 1955). The treatment has consisted of daily intramuscular injections of corticotrophin gel and the patient who has received treatment for the longest period has now completed 10 years. The passing of this milestone has prompted a review of the achievements and the problems of this form of therapy, the only similar detailed review having been made 5 years ago (West, 1957). Of great interest is the interpretation of the findings, which will be considered in the discussion.

\section{The Patients}

More than 4,000 patients suffering from R.A. or A.S. have been referred to this Centre for treatment during the period of study. A number have been given ACTH for adrenal function tests, to restimulate suppressed adrenals, or as planned short courses. The 94 patients reported on below comprise all those for whom maintenance therapy has been attempted since 1952. Although R.A. affects three to four times more women than men, 35 of the 77 rheumatoid patients treated were men. This was because inability to work is more serious for the wage-earner than for the housewife and the pressure to use powerful therapeutic agents is greater. In selecting patients for ACTH therapy, their intelligence and their ability to inject themselves had to be considered. Many could only manipulate a syringe after therapy was under way.

* Director of the Rheumatism Research Unit, Nether Edge Hospital, and part-time member of the external staff of the Medical Research Council.
All the patients had been treated with aspirin and other analgesics; thirty of the 77 R.A. patients had had gold injections over long periods; fourteen of the seventeen A.S. patients had had courses of deep $x$-ray therapy; and 31 of the total had previously had exogenous corticosteroid therapy.

\section{Methods}

ACTH therapy was begun in hospital and, with very few exceptions, all patients subsequently gave their own injections at home. No dietary restrictions were made and no supplementary potassium or "anabolic" steroids were given.

Dosage.-ACTH was given in the "gel" form into the muscle of the outer aspect of the thigh. Such a dose was given, at 6 p.m. or thereabouts, as would produce the following effects: A major reduction of stiffness by bedtime, a night free from discomfort, a stiffness-free morning, and a return of true rheumatic stiffness by teatime. That the degree of adrenal stimulation necessary to achieve these effects was not excessive was confirmed by urinary assays of 17-KGS or 17(OH)CS, before each patient left hospital. (In practice some patients were allowed to have too much in the early years of the study.)

Follow-up.-Once satisfactorily established on therapy, patients returned every 4 weeks for assessment, bringing with them a 24-hour specimen of urine. At each visit records were made of body weight, strength of grip, blood pressure, erythrocyte sedimentation rate (E.S.R.), haemoglobin concentration, and white blood count. Patients with A.S. had periodic records made of their posture and vital capacity. Dosage was adjusted on clinical grounds and subsequently reviewed when the 24-hour urine specimens had been assayed. The dose was reduced when there were no rheumatic symptoms at injection time, and was increased if symptoms (other than those occasioned by the use of damaged weightbearing joints) recurred by the early afternoon. Some patients with very active disease could not be kept free beyond midday without excessive adrenal stimulation. Prolonged experience had led to the adoption of $20 \mathrm{mg}$. as the maximum daily excretion of $17(\mathrm{OH}) \mathrm{CS}$ for prolonged therapy in a small adult and $30 \mathrm{mg}$. for a large adult. 
RADIOLOGICAL AND OTHER DATA IN RESPECT OF AI

\begin{tabular}{|c|c|c|c|c|c|c|}
\hline \multirow{3}{*}{$\begin{array}{l}\text { Patient } \\
\text { No. }\end{array}$} & \multirow{3}{*}{ Sex } & \multicolumn{2}{|c|}{ At Start } & \multirow{3}{*}{ Before ACTH Therapy } & \multicolumn{2}{|c|}{ Radiological Change } \\
\hline & & & & & & During ACT寅 \\
\hline & & $\begin{array}{l}\text { Age } \\
\text { (yrs) }\end{array}$ & $\begin{array}{l}\text { Rheumatoid } \\
\text { Arthritis } \\
\text { (yrs) }\end{array}$ & & $\begin{array}{c}\text { Interval } \\
\text { (yrs) }\end{array}$ & 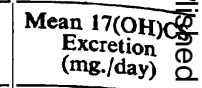 \\
\hline $\mathbf{A}$ & $\mathbf{M}$ & 47 & 5 & Osteoporosis increased in previous $4 \mathrm{mths}$ & 3 & 24 \\
\hline B1 & $\mathbf{M}$ & 47 & $2 \frac{1}{2}$ & $\begin{array}{l}\text { Gross advance in porosis and erosions in previous } \\
5 \mathrm{mths}\end{array}$ & 4 & 28 \\
\hline B2 & $\mathbf{M}$ & 15 & 4 mths & $\begin{array}{l}\text { Osteoporosis } \\
\text { Severe febrile onset }\end{array}$ & 4 & iv \\
\hline B3 & $\mathbf{M}$ & 33 & 2 & $\begin{array}{l}\text { Erosions } \\
\text { Treated for relapse during cortisone therapy }\end{array}$ & 1 & 23 \\
\hline B4 & $\mathbf{F}$ & 68 & 3 & $\begin{array}{l}\text { Mild osteoporosis, early erosion } \\
\text { Soft-tissue calcification-scleroderma }\end{array}$ & 4 & 25 \\
\hline $\mathrm{Cl}$ & $\mathbf{M}$ & 46 & 8 & $\begin{array}{l}\text { New erosions and increased destruction in preceding } \\
1 \frac{1}{2} \text { yrs }\end{array}$ & $6 \frac{1}{2}$ & 22 \\
\hline $\mathrm{C2}$ & $\mathbf{M}$ & 30 & 4 & $\begin{array}{l}\text { New erosions and increased destruction in preceding } \\
4 \mathrm{mths}\end{array}$ & $3 \frac{1}{\mathbf{z}}$ & $\frac{\mathbb{D}}{\mathrm{D}}$ \\
\hline C3 & $\mathbf{F}$ & 32 & $5 \frac{1}{2}$ & $\begin{array}{l}\text { No previous } x \text { ray } \\
\text { Treated for relapse on cortisone therapy }\end{array}$ & 1 & $\frac{3}{\mathbb{D}}$ \\
\hline D1 & $\mathbf{F}$ & 17 & $7 \mathrm{mths}$ & $\begin{array}{l}\text { No previous } x \text { ray } \\
\text { Severe febrile onset }\end{array}$ & $1 \frac{1}{2}$ & 35 응 \\
\hline D2 & $\mathbf{M}$ & 44 & 10 & $\begin{array}{l}\text { No previous } x \text { ray } \\
\text { Unable to work, lost } 12.5 \mathrm{~kg} \text {. in weight }\end{array}$ & $3 \mathbf{z}$ & 22 흘ㅁㅇㅁ \\
\hline D3 & $\mathbf{M}$ & 51 & 3 & $\begin{array}{l}\text { No previous } x \text { ray } \\
\text { Treated because "off work, losing weight, and } \\
\text { despairing" }\end{array}$ & 8 & ఏ \\
\hline D4 & $\mathbf{M}$ & 40 & $6 \mathrm{mths}$ & $\begin{array}{l}\text { No previous } x \text { ray } \\
\text { Treated because febrile, losing weight, and at "end } \\
\text { of tether" }\end{array}$ & 6 & 这 \\
\hline $\mathbf{E}$ & $\mathbf{F}$ & 33 & 5 & No previous $x$ ray & 7 & 告 \\
\hline G1 & $\mathbf{M}$ & 55 & 3 & New erosions in previous year, off work $1 \mathrm{yr}$ & 17 & $\frac{\widehat{\nwarrow}}{\grave{2}}$ \\
\hline G2 & $\mathbf{F}$ & 34 & 5 & New erosions in previous $1 \frac{1}{2}$ yrs & $2 \frac{1}{2}$ & 23 \\
\hline $\mathbf{H}$ & $\mathbf{F}$ & 23 & 2 & $\begin{array}{l}\text { Gross advance in porosis and new erosions in } \\
\text { previous } 8 \mathrm{mths}\end{array}$ & 2 & 을 \\
\hline $\mathbf{K}$ & $\mathbf{F}$ & 37 & $1+$ & Osteoporosis in previous year & 8 & 윽 \\
\hline $\mathbf{L 1}$ & $\mathbf{M}$ & 29 & 12 & $\begin{array}{l}\text { Ankylosing spondylitis with hands and feet severely } \\
\text { affected }\end{array}$ & $1 \frac{1}{2}$ & 을. \\
\hline L2 & $\mathbf{F}$ & 49 & 1 & $\begin{array}{l}\text { Osteoporosis and erosions developed in first year } \\
\text { Low grade fever }\end{array}$ & 2 & 21 \\
\hline M1 & $\mathbf{F}$ & 36 & $9 \mathrm{mths}$ & Major increase in osteoporosis in preceding $6 \mathrm{mths}$ & 5 & 18 \\
\hline M2 & $\mathbf{F}$ & 44 & 4 & No previous $x$ ray & 1 & $\stackrel{0}{c}$ \\
\hline M3 & $\mathbf{M}$ & 46 & 12 & No previous $x$ ray & 2 & 27 \\
\hline
\end{tabular}


PATIENTS WHO HAD HAD ACTH FOR AT LEAST A YEAR

\begin{tabular}{|c|c|c|c|c|c|c|c|c|}
\hline \multirow{2}{*}{\multicolumn{2}{|c|}{ Hands }} & \multicolumn{6}{|c|}{ Change Over Same Period in: } & \multirow{4}{*}{$\begin{array}{l}\text { Present Therapy and } \\
\text { Comment on Clinical Status }\end{array}$} \\
\hline & & \multicolumn{2}{|c|}{ Grip } & \multirow{2}{*}{\multicolumn{2}{|c|}{$\begin{array}{c}\text { E.S.R. } \\
\text { (Wintrobe) } \\
\end{array}$}} & \multirow{2}{*}{\multicolumn{2}{|c|}{$\begin{array}{l}\text { Weight } \\
\text { (kg.) }\end{array}$}} & \\
\hline \multirow{2}{*}{$\begin{array}{l}\text { No. of } \\
\text { Erosions } \\
\text { at Start }\end{array}$} & \multirow{2}{*}{$\begin{array}{l}\text { No. of } \\
\text { New } \\
\text { Erosions }\end{array}$} & \multicolumn{2}{|c|}{ Right + Left } & & & & & \\
\hline & & 1 & 2 & 1 & 2 & 1 & 2 & \\
\hline 0 & $\begin{array}{l}\text { 0 } \\
\text { (Osteoporosis mar- } \\
\text { kedly less) }\end{array}$ & 290 & 520 & 25 & 14 & $68 \cdot 5$ & 79 & $\begin{array}{l}\text { On oral corticosteroids (C.S.) for } 3 \frac{1}{2} \text { yrs } \\
\text { F.C. } 1 \frac{1}{2} \text { excellent }\end{array}$ \\
\hline 13 & $\begin{array}{l}2 \\
\text { (Gross advance in } \\
\text { old erosions) }\end{array}$ & 200 & 285 & 28 & 7 & $62 \cdot 5$ & $65 \cdot 5$ & $\begin{array}{l}\text { Died } 2 \text { yrs after stopping ACTH(4) of carcinoma } \\
\text { of the bronchus }\end{array}$ \\
\hline 0 & $\begin{array}{c}0 \\
\text { (Cartilage loss) }\end{array}$ & 150 & 500 & 50 & 9 & 44 & $54 \cdot 5$ & $\begin{array}{l}\text { On oral C.S.(1) for last } 4 \text { yrs. Deterioration } \div+ \\
\text { Amyloidosis } \\
\text { F.C.3 }\end{array}$ \\
\hline 2 & 0 & 510 & 520 & 50 & 30 & $8 \cdot 25$ & 90 & $\begin{array}{l}\text { On oral C.S.(2) for last } 6 \frac{1}{2} \text { yrs. Working } \\
\text { F.C. } 3 \text { due to damaged knees }\end{array}$ \\
\hline 2 & 0 & 110 & 235 & 27 & 25 & $50 \cdot 5$ & 64 & $\begin{array}{c}\text { On oral C.S.(1). Now aged 76. Well. No } \\
\text { relapse }\end{array}$ \\
\hline 17 & $\begin{array}{c}9 \\
\text { (Gross advance) }\end{array}$ & 120 & 275 & 56 & 30 & 62 & $67 \cdot 5$ & $\begin{array}{l}\text { ACTH. Goes fishing. } \\
\text { Most joints grossly damaged but F.C. } 3\end{array}$ \\
\hline 4 & $\begin{array}{c}0 \\
\text { (Erosions hardened) }\end{array}$ & 305 & 480 & 30 & 11 & $55 \cdot 5$ & 55 & $\begin{array}{l}\text { ACTH. Working } \\
\text { F.C.2 }\end{array}$ \\
\hline 0 & 0 & 140 & 155 & 50 & 14 & $71 \cdot 5$ & 88 & $\begin{array}{l}\text { Died } 1 \text { yr after stopping ACTH(2) following } \\
\text { operation for perforated diverticulum }\end{array}$ \\
\hline 0 & 0 & 120 & 520 & 53 & 21 & 77 & 66 & $\begin{array}{l}\text { Off ACTH } 1 \frac{1}{2} \text { yrs(3) } 30 \text { only local relapse. Well } \\
\text { and working, but } 20 \text { erosions now present } \\
\text { F.C. } 2\end{array}$ \\
\hline 10 & $\begin{array}{c}0 \\
\text { (Cartilage loss) }\end{array}$ & 210 & 420 & 37 & 15 & 65 & 68 & $\begin{array}{l}\text { On C.S. ( } 4 \text { yrs)(1). Loses no time from work } \\
\text { F.C.2. }\end{array}$ \\
\hline 4 & 0 & 151 & 520 & 3 & 4 & $79 \cdot 5$ & 86 & $\begin{array}{l}\text { ACTH. Appears very well } \\
\text { F.C.1 }\end{array}$ \\
\hline 0 & 0 & 225 & 520 & 49 & 25 & $67 \cdot 5$ & $78 \cdot 5$ & $\begin{array}{l}\text { ACTH. Appears very well } \\
\text { F.C.1 }\end{array}$ \\
\hline 13 & $\begin{array}{l}\text { (Advance in some } \\
\text { old erosions) }\end{array}$ & 110 & 258 & 47 & 25 & 45 & $54 \cdot 5$ & $\begin{array}{l}\text { ACTH. Partial gastrectomy before ACTH. } \\
\text { Period includes } 1 \text { yr (4th-5th) on oral C.S. }\end{array}$ \\
\hline 9 & 0 & 240 & 470 & 37 & 24 & 68 & 81 & $\begin{array}{l}\text { Died of bilateral lobar pneumonia while on } \\
\text { ACTH. (Organisms not sensitive to anti- } \\
\text { biotic given) }\end{array}$ \\
\hline 16 & $\begin{array}{c}0 \\
\text { (Improved) }\end{array}$ & 185 & 440 & 52 & 14 & $45 \cdot 5$ & 55 & $\begin{array}{l}\text { Changed to C.S.(4) on emigrating } \\
\text { F.C.2 }\end{array}$ \\
\hline 4 & 0 & 120 & 220 & 62 & 41 & $47 \cdot 5$ & $64 \cdot 5$ & $\begin{array}{l}\text { ACTH. Well } \\
\text { F.C.2 }\end{array}$ \\
\hline 0 & 0 & 150 & 135 & 26 & 6 & 48 & 57 & 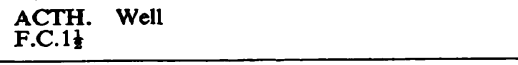 \\
\hline $\begin{array}{c}0 \\
\text { (Osteoporosis } \\
\text { only }+++ \text { ) }\end{array}$ & $\begin{array}{l}0 \\
\text { (Osteoporosis } \\
\text { reversed) }\end{array}$ & 160 & 460 & 25 & 18 & 53 & 79 & $\begin{array}{l}\text { On oral C.S.(2) for last } 8 \text { yrs. Working but } \\
\text { F.C. } 3 \frac{1}{2}\end{array}$ \\
\hline 0 & 0 & 120 & 520 & 62 & 22 & $46 \cdot 5$ & $51 \cdot 5$ & $\begin{array}{l}\text { On oral C.S.(2) for last } 3 \frac{1}{2} \text { yrs. Little deteriora- } \\
\text { tion } \\
\text { F.C. } 2\end{array}$ \\
\hline 0 & 1 & 160 & 400 & 38 & 15 & 56.5 & 60 & $\begin{array}{l}\text { ACTH. Well } \\
\text { F.C. } 1 \frac{1}{2}\end{array}$ \\
\hline 0 & 0 & 250 & 520 & 57 & 41 & $75 \cdot 5$ & 75 & $\begin{array}{l}\text { On C.S.(1) for last } 7 \text { yrs. Some deterioration } \\
\text { F.C.3. (Knees) }\end{array}$ \\
\hline 13 & 0 & 140 & 240 & 25 & 14 & 59 & 79 & $\begin{array}{l}\text { On C.S.(1) } 2 \text { yrs after change developed crush } \\
\text { fracture of lumbar vertebrae. Well } \\
\text { F.C. } 3 \frac{1}{2} \text { (hips) }\end{array}$ \\
\hline
\end{tabular}




\begin{tabular}{|c|c|c|c|c|c|c|}
\hline \multirow{3}{*}{$\begin{array}{l}\text { Patient } \\
\text { No. }\end{array}$} & \multirow{3}{*}{$\operatorname{Sex}$} & \multicolumn{2}{|c|}{ At Start } & \multirow{3}{*}{ Before ACTH Therapy } & \multirow{2}{*}{\multicolumn{2}{|c|}{ Radiological Chiange }} \\
\hline & & & $\begin{array}{c}\text { Duration } \\
\text { of }\end{array}$ & & & \\
\hline & & $\begin{array}{l}\text { Age } \\
\text { (yrs) }\end{array}$ & $\begin{array}{l}\text { Rheumatoid } \\
\text { Arthritis } \\
\text { (yrs) }\end{array}$ & & $\begin{array}{l}\text { Interval } \\
(y \mathrm{rs})\end{array}$ & $\begin{array}{l}\text { Mean } 17(\mathrm{O}) \mathrm{H} ; \mathrm{C} \\
\text { Excre:ion } \\
\text { (mg. dia) }\end{array}$ \\
\hline M4 & $\mathbf{M}$ & 21 & $3 \frac{1}{2}$ & Gross damage in 3 yrs preceding $\mathrm{ACTH}$ & 6 & 25 \\
\hline M5 & $\mathbf{M}$ & 38 & 2 & $\begin{array}{l}\text { No previous } x \text { ray } \\
\text { Lost } 4 \cdot 5 \mathrm{~kg} \text {. in } 6 \mathrm{mths} \\
\text { "End of tether" }\end{array}$ & $4 \frac{1}{2}$ & 25 \\
\hline $\mathrm{O}$ & $\mathbf{M}$ & 45 & 12 & $\begin{array}{l}\text { New erosions and increased destruction in pre- } \\
\text { existing erosions in previous } 2 \text { yrs }\end{array}$ & 4 & $\therefore 1$ \\
\hline $\mathbf{P}$ & $\mathbf{M}$ & 47 & 18 & $\begin{array}{l}\text { No previous } x \text { ray } \\
\text { Treated primarily for loss of vision due to iritis }\end{array}$ & 3 & 25 \\
\hline $\mathbf{R}$ & $\mathbf{M}$ & 34 & 1 & $\begin{array}{l}\text { Osteoporosis only } \\
\text { Lost } 25 \mathrm{~kg} \text {. before therapy }\end{array}$ & 1 & 15 \\
\hline S1 & $\mathbf{F}$ & 42 & $2 \frac{1}{2}$ & $\begin{array}{l}\text { Many erosions in first } 2 \text { yrs } \\
\text { Iritis }\end{array}$ & 7 & 15 \\
\hline $\mathbf{S} 2$ & $\mathbf{M}$ & 37 & $6 \mathrm{mths}$ & Osteoporosis & 2 & 40 \\
\hline$T$ & $\mathrm{~F}$ & 35 & 17 & No previous $x$ ray & $4 k$ & 18 \\
\hline W1 & $\mathrm{F}$ & 60 & 12 & $\begin{array}{l}\text { Marked advance and new erosions in previous year } \\
\text { On oral C.S. for } 8 \text { yrs }\end{array}$ & 1 & 21 \\
\hline W2 & $\mathrm{F}$ & 30 & 5 & $\begin{array}{l}\text { Extreme osteoporosis occurred during } 6 \mathrm{mths} \text { bee- } \\
\text { sting therapy } \\
\text { Previously on oral C.S. for } 4 \mathrm{yrs}\end{array}$ & 1 & 25 \\
\hline W3 & $\mathbf{F}$ & 54 & 2 & $\begin{array}{l}\text { No previous } x \text { ray } \\
\text { Treated because febrile and losing weight }\end{array}$ & 2 & 16 \\
\hline W4 & $\mathbf{F}$ & 40 & 13 & $\begin{array}{l}\text { New erosions and increased osteoporosis in previous } \\
1 \frac{1}{2} \text { yrs }\end{array}$ & $4 \frac{1}{2}$ & 23 \\
\hline$Y$ & $\mathbf{M}$ & 63 & 1 & $\begin{array}{l}\text { Internal erosions only } \\
\text { Treated for prolonged fever }\end{array}$ & 2 & 21 \\
\hline Means . . & . & 41 & 5 & & $3 \frac{1}{2}$ & 25 \\
\hline
\end{tabular}

Notes: F.C. - Functional Capacity, graded from $1=$ normal to $5=$ bedfast and helpless.

Reasons for stopping ACTH: (1) Acquired resistance (2) Hypertension (3) Remission (4) Social

\section{Results}

Table I (overleaf) gives particulars of all the R.A. patients plus one A.S. patient with hand involvement, who received ACTH therapy for at least one year.

In comparing the effects of therapeutic agents upon the course of rheumatoid arthritis, the most objective and unequivocal sign to follow is that of the appearance of new bone erosions. Unfortunately this sign has been recorded in very few published trials, but there is relevant data in the recent Empire Rheumatism Council gold trial (1961).

Table II (opposite) shows that the ACTH-treated patients of Table I fared very much better than the gold trial patients. The problem is to decide whether factors other than those of the therapy used could have accounted for the remarkable differences. The ACTH group differed in including relatively more males but a study of the progress of each patient (to date) reveals that the disease has not run a less severe course in the males than in the females. The inclusion of patients with disease of short duration is likely to favour the results but again a study of the progress of such patients in the ACTH group shows that, on average, they have run a more severe course than the others. In the gold trial, 22 per cent. of the patients fell by the way. Their exclusion from the results will have improved the "gold and 


\begin{tabular}{|c|c|c|c|c|c|c|c|c|}
\hline & & \multicolumn{6}{|c|}{ Change Over Same Period in: } & \multirow{4}{*}{$\begin{array}{l}\text { Present Therapy and } \\
\text { Comment on Clinical Status }\end{array}$} \\
\hline apy & & \multicolumn{2}{|c|}{$\underset{(\mathrm{mm} . \mathbf{H g})}{\text { Grip }}$} & \multirow{2}{*}{\multicolumn{2}{|c|}{$\begin{array}{c}\text { E.S.R. } \\
\text { (Wintrobe) }\end{array}$}} & \multirow{2}{*}{\multicolumn{2}{|c|}{$\begin{array}{l}\text { Weight } \\
\text { (kg.) }\end{array}$}} & \\
\hline \multirow{2}{*}{$\begin{array}{l}\text { No. of } \\
\text { Erosions } \\
\text { at Start }\end{array}$} & \multirow{2}{*}{$\begin{array}{l}\text { No. of } \\
\text { New } \\
\text { Erosions }\end{array}$} & Right & Left & & & & & \\
\hline & & 1 & 2 & 1 & 2 & 1 & 2 & \\
\hline 27 & $\begin{array}{c}0 \\
\text { (Advance in } \\
\text { existing damage) }\end{array}$ & 100 & 410 & 28 & 6 & $47 \cdot 5$ & $49 \cdot 5$ & $\begin{array}{l}\text { ACTH. Well. Working } \\
\text { F.C.3 }\end{array}$ \\
\hline 0 & $\mathbf{0}$ & 345 & 457 & 43 & 21 & $76 \cdot 5$ & 85 & $\begin{array}{l}\text { ACTH. Well } \\
\text { F.C.1 }\end{array}$ \\
\hline 9 & $\mathbf{0}$ & 140 & 415 & 27 & 8 & 73 & $78 \cdot 5$ & $\begin{array}{l}\text { On C.S.(2) } 3 \text { yrs. Some deterioration } \\
\text { F.C. } 21\end{array}$ \\
\hline 20 & $\mathbf{0}$ & 160 & 210 & 45 & 15 & 57 & 63 & $\begin{array}{l}\text { ACTH. No recurrence of eye inflammation } \\
\text { F.C. } 2 \frac{1}{2}\end{array}$ \\
\hline $\mathbf{0}$ & $\mathbf{0}$ & 210 & 510 & 35 & 13 & 91 & 110 & $\begin{array}{l}\text { ACTH. Well } \\
\text { F.C.2 }\end{array}$ \\
\hline 10 & $\begin{array}{c}5 \\
\begin{array}{c}\text { (Advance in some } \\
\text { old erosions) }\end{array}\end{array}$ & 160 & 370 & 43 & 35 & 58 & 64 & $\begin{array}{l}\text { Off ACTH } 1 \frac{1}{2} \text { yrs (3). No relapse except in iritis. } \\
\text { Eyes normal throughout ACTH therapy }\end{array}$ \\
\hline 0 & $\mathbf{0}$ & 260 & 520 & 44 & 20 & 65 & 75 & $\begin{array}{l}\text { On C.S.(2) last } 6 \frac{1}{2} \text { years. Disease has run a } \\
\text { severe course } \\
\text { F.C. } 3 \frac{1}{1}\end{array}$ \\
\hline $\mathbf{0}$ & $\mathbf{0}$ & 225 & 520 & 34 & 9 & $46 \cdot 5$ & $68 \cdot 5$ & $\begin{array}{l}\text { Off treatment } 1 \text { yr(3). No relapse } \\
\text { F.C. } 1 \frac{1}{2}\end{array}$ \\
\hline 17 & $\begin{array}{c}\mathbf{0} \\
\text { (Erosions hardened) }\end{array}$ & 108 & 135 & 11 & 6 & $49 \cdot 5$ & 56 & $\begin{array}{l}\text { ACTH } \\
\text { F.C.3 }\end{array}$ \\
\hline 12 & $\begin{array}{l}\text { o } \\
\text { (Major decrease in } \\
\text { osteoporosis) }\end{array}$ & 0 & 135 & 48 & 16 & 49 & 67 & $\begin{array}{l}\text { On oral C.S. for } 9 \text { mths(1). While on ACTH } \\
\text { changed from F.C.5 to F.C.21 - still main- } \\
\text { tained }\end{array}$ \\
\hline 0 & $\begin{array}{c}0 \\
\text { (Less osteoporosis) }\end{array}$ & 130 & 220 & 28 & 6 & 51 & $63 \cdot 5$ & $\begin{array}{l}\text { ACTH. Well } \\
\text { F.C.2 }\end{array}$ \\
\hline 15 & $\begin{array}{l}\text { (Advance in many } \\
\text { old erosions) }\end{array}$ & 233 & 295 & 45 & 41 & 70 & 71 & $\begin{array}{l}\text { ACTH. Well } \\
\text { F.C.21 }\end{array}$ \\
\hline 0 & 0 & 275 & 420 & 34 & 24 & $60 \cdot 5$ & $61 \cdot 5$ & $\begin{array}{l}\text { Died } 8 \text { mths after change to oral C.S.(4). Lost } \\
\text { desire to live after wife's death }\end{array}$ \\
\hline $6 \cdot 5$ & 0.75 & 192 & 388 & 40 & 19 & 62 & $71 \cdot 5$ & \\
\hline
\end{tabular}

TABLE II

DATA FROM THE EMPIRE RHEUMATISM COUNCIL'S GOLD TRIAL COMPARED WITH DATA FOR 34 RHEUMATOID ARTHRITIC PATIENTS FROM TABLE I

\begin{tabular}{|c|c|c|c|c|c|c|c|c|c|c|c|}
\hline \multirow{2}{*}{\multicolumn{2}{|c|}{ Therapy }} & \multicolumn{3}{|c|}{ Number of Patients } & \multirow{2}{*}{$\begin{array}{c}\text { Mean } \\
\text { Age } \\
\text { (yrs) }\end{array}$} & \multirow{2}{*}{$\begin{array}{c}\text { Mean } \\
\text { Duration of } \\
\text { Rheumatoid } \\
\begin{array}{c}\text { Arthritis } \\
\text { (yrs) }\end{array}\end{array}$} & \multirow{2}{*}{$\begin{array}{c}\text { Mean No. } \\
\text { of Hand } \\
\text { Erosions }\end{array}$} & \multirow{2}{*}{$\begin{array}{c}\text { Interval } \\
\text { (yrs) }\end{array}$} & \multirow{2}{*}{$\begin{array}{c}\text { Mean No. } \\
\text { of New } \\
\text { Erosions }\end{array}$} & \multirow{2}{*}{$\begin{array}{l}\text { Mean } \\
\text { Change in } \\
\text { Erythrocyte } \\
\text { Sedimenta- } \\
\text { tion Rate }\end{array}$} & \multirow{2}{*}{$\begin{array}{l}\text { Mean } \\
\text { Change in } \\
\text { Grip } \\
\text { Both Hands } \\
\text { (mm. Hg) }\end{array}$} \\
\hline & & $\mathbf{M}$ & $\mathbf{F}$ & Total & & & & & & & \\
\hline \multirow{2}{*}{ E.R.C. } & Gold & 22 & 25 & 47 & $48 \cdot 5$ & c3. 5 & c7 & $2 \frac{1}{2}$ & c5 & $\begin{array}{c}c 42-32 \\
(\mathrm{Wg} .)\end{array}$ & $298-335$ \\
\hline & $\begin{array}{l}\text { Control } \\
\text { for Gold }\end{array}$ & 23 & 59 & 82 & $48 \cdot 4$ & c3 5 & c7 & $2 \frac{1}{2}$ & c7 & $\begin{array}{c}\text { c39_-32 } \\
(\mathrm{Wg} .)\end{array}$ & $290-315$ \\
\hline ACTH & $\cdots$ & 18 & 16 & $34^{*}$ & 41 & 5 & $6 \cdot 5$ & $3 \frac{1}{2}$ & $\begin{array}{r}0 \cdot 75 \\
(\text { mean })\end{array}$ & $\begin{array}{c}40-19 \\
(\mathrm{~Wb} .)\end{array}$ & $192-388$ \\
\hline
\end{tabular}

* Of the 34 ACTH patients, fourteen had already received prolonged gold therapy ànd seven prolonged oral corticosteroid therapy -and they were deteriorating. 
control" results given, since many left the trial because they were deteriorating.

Rheumatoid Arthritis.-Of the 77 ACTH-treated R.A. patients, 37 stopped treatment before completing one year of therapy.

Inadequate Relief.-Only one stopped because the adrenal stimulation gave inadequate relief. He was changed to oral corticosteroids and within 2 years was chair-fast from gross bone destruction and amyloid hepatomegaly. Could the reasons for stopping therapy in the other patients have selectively removed the most severe cases? An account of what has happened to them is necessary.

Acquired Resistance.-22 patients did not complete a year of ACTH therapy because they developed "acquired resistance" to the ACTH. This phenomenon, which does not imply any loss of effectiveness of the adrenal stimulation, will be discussed below. Twelve of the 22 have since received small doses of oral corticosteroids and have deteriorated little. Of the remaining ten, six are dead and of the four alive, three are severely crippled. All three had had prolonged oral corticosteroid therapy before receiving ACTH. The causes of death of the six were as follows:

(1) Polyarteritis nodosa, after a further 6 months' oral corticosteroid (he had developed pituitary failure, due to local suppuration, before the R.A. appeared).

(2) Polyarteritis nodosa, after a further 3 years' oral corticosteroid.

(3) Cerebral haemorrhage, after a further 4 years' oral corticosteroid.

(4) Coronary thrombosis, after a further 4 years' oral corticosteroid.

(5) Congestive cardiac failure secondary to hypertension, after a further 6 years' oral corticosteroid.

(6) Died in mental hospital, cause of death not known, after a further $1 \frac{1}{2}$ years' oral corticosteroid.

The first of these patients had little articular damage, the other five had considerable damage but only became severely disabled before the terminal illness.

It is clear that the development of acquired resistance to ACTH did remove some severe and complicated cases from the treatment group, but, from the numbers, it cannot be said that the acquired resistance removed them selectively. Of the ten whose R.A. deteriorated or who died, seven had been given ACTH because they were deteriorating on oral corticosteroid, and therefore comprised a highly selected group.
Remission.-Four stopped therapy because they were in complete or partial remission.

Social Reasons.-Four stopped for social reasons connected with the giving of the injections.

Miscellaneous Reasons.-Six patients stopped (hypertension (2), objection to weight gain (2), marked fluid retention (1), the development of peripheral neuritis (1)). This last patient was changed to prednisolone and died of polyarteritis nodosa 2 years later. The R.A. of the six miscellaneous patients was not running a severe course.

Six patients remain on ACTH therapy who have not yet had a one-year $x$-ray follow-up.

It is concluded that those patients who stopped ACTH therapy before the completion of one year included several whose disease has run a severe course, but that the reason for stopping ACTH therapy was not related, except in one case, to the severity of their disease and their exclusion from the trial group cannot account for the favourable results shown in Table II.

Ankylosing Spondylitis.-Seventeen patients, thirteen men and four women, received ACTH for a mean period of 3 years. Fourteen have stoppe ACTH for the following reasons:

Remission.-Nine are in partial or complete remission.

Acquired Resistance.-Two stopped because of acquired resistance and are on oral corticosteroids.

Hypertension.-Two stopped because of hypertension and are on oral corticosteroids.

Amyloidosis.-One developed amyloidosis which became apparent a year after he had been changed to prednisolone because of hypertension. He died 3 years later of cerebral haemorrhage. His brother died of amyloidosis secondary to ankylosing spondylitis and received only small doses of corticosteroids after signs of Addison's disease had developed.

The three patients remaining on ACTH therapy have now completed $4,8 \frac{1}{2}$, and 10 years of daily injections respectively.

The patient who has had $8 \frac{1}{2}$ years' therapy was treated because her hip joints were affected. She had had several courses of deep $x$-ray therapy and had had ulcerative colitis and four attacks of iritis, but has since been well and actively running her home. She is obese but attributes this to a family trait. Her blood pressure has risen from 120/80 to $150 / 95$. Her mean level of daily $17(\mathrm{OH}) \mathrm{CS}$ excretion over the $8 \frac{1}{2}$ years has been $21 \mathrm{mg}$. 
The patient who had had 10 years' therapy was treated because her symptoms relapsed within 2 months of deep $x$-ray therapy. She has been well and active throughout the 10 years and is loathe to stop the therapy. Her mean $17(\mathrm{OH}) \mathrm{CS}$ excretion has been $23 \mathrm{mg}$. and her blood pressure is 150/100. She has a mild general pigmentation most noticeable in exposed parts of the body.

\section{Complications}

(1) Acquired Resistance to ACTH.-This is the major obstacle to the prolonged use of ACTH. In this study acquired resistance has been said to exist when, to maintain the initial satisfactory level of adrenal stimulation, the dose of ACTH had had to be raised progressively to about 40 units. The limit of $\mathbf{4 0}$ units was set for economic reasons. In the course of a number of studies the dose has been raised to much higher levels. The subject has already been reviewed extensively (West, 1960). Since 1960 we have made two studies which remain unpublished.

In the first, done in collaboration with Dr. G. Owen and Dr. F. Miller, 131I labelled C.O.C. purified corticotropin and highly purified corticotropin $A_{1}$ (kindly supplied by Dr. H. B. F. Dixon) were used. It was found that "acquired resistance" was associated with an abnormally rapid disappearance of the ${ }^{131} \mathrm{I}$ from the muscle depot of labelled corticotropin in gelatine and with an abnormally rapid excretion of the ${ }^{131} I$ in the urine. Radioactivity counts over the left adrenal suggested that the corticotropin accumulated in the adrenal of the normal control but not in that of the patient with acquired resistance.

In the second study, Dr. J. R. Hodges added the serum from a patient with acquired resistance to ACTH and gave it to twelve rats. Another twelve rats received ACTH alone. The effectiveness of the ACTH was measured by a modified Sayers's assay (Sayers, Sayers, and Woodbury, 1948), and it was found that the response of the serum-treated group was reduced, but the result fell just short of being "significant" at the 5 per cent. level.

The mechanism responsible for the acquired resistance has yet to be discovered, as has the mechanism by which ACTH is normally destroyed. When some means is found of preventing "acquired resistance" ACTH therapy will be much simpler and much less expensive. In theory 3 to 4 units per day should be sufficient for therapy, but the mean dose of ACTH (in gelatine) being given to patients at this Centre at the present time is 30 units (range 8 to 72 ).
(2) Cushing's Syndrome.-The aim has been to maintain adrenal stimulation at a level below that at which the signs and symptoms of Cushing's syndrome might appear. For the most part this has been achieved.

Obesity.-The mean weight gains of $9.5 \mathrm{~kg}$., recorded in Table I, has been accompanied by very little obesity. Most of the patients started at a weight much below their best before developing R.A. The few patients who did become mildly obese were women who had previously been well-covered or who were passing the menopause.

\section{Cutaneous Striae.-No patients developed striae.}

Hypertension.-When hypertension occurred it fluctuated with the level of adrenal stimulation, but many patients showed no signs of a rise in blood pressure even when over-stimulated. It appears that, at the level of adrenal stimulation given, the few who develop hypertension have an inherited predisposition to do so.

Osteoporosis.-One patient was trodden on and sustained a fractured rib. His adrenal stimulation had been excessive for a long time and the fracture may well have been pathological. One patient had a partial collapse of a lumbar vertebra after 4 months' ACTH therapy. She had had exogenous corticosteroid therapy for the previous 6 years. No other fractures or $x$-ray evidence of generalized osteoporosis were noted.

Diabetes.-Glycosuria was noted occasionally in a few patients when the level of stimulation was excessive -not otherwise.

(3) Peptic Ulceration.-Gastric symptoms have been remarkably few. Several patients had symptoms after changing to oral corticosteroids and in two haematemesis led to partial gastrectomies. One of the rheumatoid men had melaena. At the time the adrenal stimulation was only moderate and he was taking aspirin. The otherwise striking absence of gastric symptoms may be partly due to the fact that the ACTH-treated patients did not need to take analgesics on an empty stomach at night and in the early morning. With oral corticosteroid therapy the local concentration of steroid in the stomach, which is avoided with ACTH therapy, may contribute to ulceration.

(4) Amyloidosis.-During the period of study ten patients under surveillance at the Centre developed gross amyloidosis. No patient was so affected during ACTH therapy, but as the number of patientyears of ACTH therapy was small, compared with that of the total, this may not be of significance.

(5) Pathological Bruising.-This complication of prolonged therapy with cortisone analogues, even 
when given in conservative dosage, was not observed in ACTH-treated patients (West, 1961). It is said that patients with Cushing's syndrome bruise easily and have atrophic skin, so this could be a complication if excessive adrenal stimulation is given for a long time. It could also be that the cortisone analogues, or at least some of them, are more likely to cause this complication than the parent steroid.

(6) Infections and Wound Healing.-As a result of observing more than 180 patient-years of ACTH therapy the conclusion is reached that mild adrenal stimulation, as practised at this Centre, has not had any observable effect upon patients' responses to local or general infections or to trauma.

\section{Discussion}

The radiological findings show that, by giving a dose of ACTH sufficient to double the adrenal secretion of cortisol, many sites that would have been involved in the disease process remained normal. The mechanism by which corticosteroid hormones work is not known, but present evidence suggests that they produce their effects by moderating the rates of one or more enzyme reactions and that the nature of the overall effect depends upon the concentration available (e.g. a measurable effect increased at one concentration may be decreased at a higher concentration). It appears then that, in the case of rheumatoid arthritis, a small increase in this moderating effect on the rate of one or more enzyme reactions allows certain tissues to maintain their integrity. One may hypothesize that the rheumatoid lesion results from an inability of certain enzyme reactions, at a particular site and a particular time, to deal normally with some sort of environmental insult or autogenous antibody. As the action of the hormone is permissive, the effect it can have will depend upon the availability of the specific substrate on which it works and of other factors if the effect is indirect. In certain circumstances its effect may be little or none. In such circumstances a high concentration of an "antiinflammatory" hormone would suppress several parameters of the inflammatory reaction, but the initial lesion (which lead to the non-specific inflammation) would not resolve and the inflammation would return when the hormone level fell to near normal levels. The point made here is that, at potential sites of rheumatoid disease, tissue integrity is often maintained by concentrations of adrenal hormones that cannot be shown to interfere with the response of normal tissues to the everyday inflammation provoking agents, i.e. it is the initial lesion that is prevented, not the non-specific antiinflammatory response to the lesion.

This hypothesis applies equally to some other diseases of different tissues, which are similarly reversed by low doses of corticosteroid hormones. It attracts attention to the local abnormality rather than to the exciting agent. The latter, whether environmental or endogenous, may be an inescapable part of everyday living. The apparent nonspecificity of the action does not make it any less interesting or its elucidation any less worthwhile.

The essence of the hypothesis was expressed in the previous paper on ACTH therapy (West, 1957) and in that paper the problem why ACTH was of marked value when oral cortisone acetate was not was also discussed. Two more recent developments are relevant. One is the finding that the slow loss of effect of oral prednisolone therapy-in which the hormone is given via the portal circulation-is not avoided by giving the prednisolone via the systemic circulation (West, 1962). This suggests that the ineffectiveness of oral cortisone acetate therapy may not be due to an adaptive modification of its metabolism in the liver. The other finding is that corticosteroid bruising and purpura is not a complication of prolonged ACTH therapy. This has been referred to in the text above.

\section{Summary and Conclusions}

Prolonged adrenal stimulation therapy, checked by routine corticosteroid assays, has been attempted in 94 patients suffering from rheumatoid arthritis or ankylosing spondylitis. An account has been given of all the patients and details are given of the progress of 49 patients who received daily injections for from 1 to 10 years. Particular note has been made of the occurrence of new bone erosions of the hands; the incidence of such erosions, over a mean period of $3 \frac{1}{2}$ years, has been compared with that found over a period of $2 \frac{1}{2}$ years in the gold trial of the Empire Rheumatism Council. By comparison, the progress of the 35 ACTHtreated patients was very much better. It is concluded that mild adrenal stimulation enables sites of potential rheumatoid disease to maintain their integrity. This leads to the hypothesis that the primary lesion may be due to the inability of certain enzymes, at a particular locus, to deal normally with an environmental agent or autogenous antibody. This inability may be due to a relative deficiency of a particular factor, the activation or synthesis of which is promoted by raising the concentration of one or more adrenocortical hormones. If the deficiency is marked, or becomes so, the permissive action of the hormones may be ineffective. 
In this event, relatively high concentrations of hydrocortisone, or an analogue, would suppress the resulting non-specific inflammatory reaction but would not lead to resolution and healing.

Thanks are due to Dr. G. R. Newns for clinical help, and to the nursing and laboratory staff who made the study possible. During much of the period covered the author was a part-time Nuffield Research Fellow of the University of Sheffield.

\section{REFERENCES}

Appleby, J. I., Gibson, G., Norymberski, J. K., and Stubbs, R. D. (1955). Biochem. J., 60, 453.

Empire Rheumatism Council (1961). Ann. rheum. Dis., 20, 315 .

Norymberski, J. K., Stubbs, R. D., and West, H. F. (1953). Lancet, 1, 1276.

Sayers, M. A., Sayers, G., and Woodbury, L. A. (1948). Endocrinology, 42, 379.

West, H. F. (1957). Ann. rheum. Dis., 16, 321.

- (1960). Acta med. scand., Suppl. No. 352.

(1961). Ann. rheum. Dis., 20, 86.

_- (1962). Ibid., 21, 191.

\section{Dix ans de thérapie a l'ACTH}

\section{RÉSUMÉ}

Chez 94 malades atteints d'arthrite rhumatismale ou de spondylarthrite ankylosante on procéda à la thérapie par stimulation prolongée de la surrénale, contrôlée par des déterminations régulières des corticostéroïdes. On présente ici quelques données sur tous les malades et on décrit plus minutieusement les progrès de 49 malades atteints d'arthrite rhumatismale qui recevaient des injections quotidiennes pendant 1 à 10 ans. On nota particulièrement l'apparition de fraiches érosions osseuses dans les mains et on compara leur fréquence au cours d'une période moyenne de $3 \frac{1}{2}$ ans à celle relevée au cours d'une période de $2 \frac{1}{2}$ ans dans l'essai thérapeutique des sels d'or, conduit par l'Empire Rheumatism Council. Cette comparaison montra que les 35 malades traités par l'ACTH firent de plus grands progrès. On en conclut qu'une douce stimulation surrénale permet aux endroits potentiels de la maladie rhumatismale de maintenir leur integrité. Cela nous mène à l'hypothèse que les lésions primaires seraient dues à l'incapacité de certains enzymes, à certain endroit, de réagir normalement avec un agent ambiant ou un anticorps autogène. Cette incapacité pourrait être due à une carence relative d'un facteur particulier dont la synthèse serait activée par l'augmentation du taux d'une ou de plusieurs hormones cortico-surrénales. Si une telle carence est grande ou devient grande, l'action favorable des hormones peut-être inefficace. En tel cas, un taux relativement élevé d'hydrocortisone ou d'un analogue serait capable de supprimer la conséquente réaction inflammatoire non-spécifique, mais non pas de mener à la résolution et la guérison.

\section{Diez años de tratamiento con ACTH}

\section{SUMARIO}

En 94 enfermos con artritis reumatoide o espondilartritis anquilosante se procedió a la terapia prolongada de estimulación suprarrenal, controlada por determinaciones regulares de corticosteroides. Se presentan aquí algunos datos acerca de todos los enfermos y se describe detalladamente el progreso de 49 pacientes con artritis reumatoide tratados con inyecciones diarias durante 1 a 10 años. Se notaron en particular las erosiones óseas nuevas en las manos y su frecuencia durante un período medio de $3 \frac{1}{2}$ años dué comparada a la observada durante un período de $2 \frac{1}{2}$ años en el ensayo terapéutico de sales de oro emprendido por el Empire Rheumatism Council. Esta comparación mostró que los 35 enfermos tratados con ACTH se llevaron mucho mejor. Se concluye que una leve estimulación suprarrenal permite a los sitios potenciales de la enfermedad reumatoide de mantener su integridad. Esto nos lleva a la hipótesis de que las lesiones primarias se debieran a la incapacidad de ciertos enzimas en ciertos puntos de reaccionar con un agente ambiente o un anticuerpo autógeno. Se atribuye esta incapacidad a la carencia relativa de un factor particular cuya síntesis necesita un aumento de la concentración de una o más hormonas cortico-suprarrenales. Si tal carencia es, o llega a ser, pronunciada, la acción favorable de las hormonas puede ser poco efectiva. Entonces, una tasa relativamente alta de hidrocortisona o de su análogo aún puede suprimir la consiguiente reacción inflamatoria non-específica pero no consigue la resolución y la cura. 